And while they did identify bed shortages as an obstacle, Rowe noted that clinical efficiencies could alleviate the problem. "We can be better and more efficient at throughput within hospitals, so busy hospitals with care plans and with clinical practice guidelines might be better at treating conditions and reducing the length of stay so that those beds transition much more quickly."

In other recommendations, the report urged the development of a national emergency department database to promote additional studies and, ultimately, the adoption of best practices. - Wayne Kondro, CMAJ

DOI:I0.1503/cmaj.060596

\section{Joie de vivre sans smokes}

Publihed at www.cmaj.ca on May 3I, 2006.

A t midnight May 3I, patrons of Quebec bars and restaurants inhaled their last lungful of second-hand smoke as Canada's famously laissez-faire province declared virtually all public spaces smoke free. Quebec joined Ontario in marking the World Health Organization's World No Tobacco Day by introducing province-wide smoking bans.

Manitoba, New Brunswick, Nunavut and the Northwest Territories have had full public and workplace bans in place since 2004. In December, Nova Scotia will go $100 \%$ smoke free in public spaces and workplaces. The Non-Smokers Rights Association reports that British Columbia, Alberta, Saskatchewan, Newfoundland and Labrador and Prince Edward Island have varying degrees of provincial bans in effect but are not considered 100\% smoke free because they still allow for designated smoking rooms or areas. Canadian smokers are still largely free to light up where they please in the Yukon, which only bans smoking in government-operated buildings.

The Smoke-Free Ontario Act replaced a patchwork of rules in some I50 communities across the province. It is now illegal to smoke in bars, taverns, pool halls, taxis, bowling alleys, restaurants, private clubs, universities, bingo halls and practically any other location where members of the public get together. Smokers flouting the ban can be fined up to $\$ 600$; businesses face fines of up to $\$$ Io 000 .

In Quebec, a Statistics Canada survey in 2002 found only $26 \%$ of residents approved of smoke-free restaurants, a figure that dropped to I $8 \%$ when the topic turned to smoke-free bars. A mere 3 years later, $53 \%$ of Quebec residents said they favoured smoke-free restaurants and 36\% approved of smoke-free bars.

At the Typhoon, a neighbourhood bar in Montréal, Lorraine Albert and Dani Spencer counted down the days to Quebec's ban.

"It'll be great," said Albert, a halfpack-a-day smoker. "I plan to quit and I think it will encourage a lot of others to do the same."

"I only smoke when I drink and I'm planning to quit, too," said Spencer.

But the service sector is less than enthusiastic. A newly formed association of bar owners and restaurateurs, L'union des tenanciers de bars du Québec, is challenging Bill II2 on the grounds it violates liberty rights and freedom of association.

Meanwhile, the 600 Ontario members of the Pub and Bar Coalition of Canada are seeking a \$500-million aid package from Ontario to compensate for lost business due to the ban. "This is economic disaster for our industry," stated Vice President Randy Hughes.

Over the last decade, the number of smokers in Quebec has declined dramatically, from more than $38 \%$ of the province's total population in 1994 to approximately $23 \%$ today, reports Statistics Canada. In Ontario, the number of smokers has declined from $23 \%$ of the population in 1999 to $19 \%$ in 2005 . The question now remains whether the ban will force more people to quit.

Neil Collishaw, Research Director at Physicians for a Smoke-Free Canada, says there is evidence to suggest this is true. Cities that have banned public smoking have seen a decrease in the number of smokers compared with the provincial average. Since the smoking ban in Ottawa in 200I, adult daily smoking rates have dropped from $19 \%$ to $10.8 \%$ in 2005. "The ban is certainly part of the explanation for the drop," says Collishaw, "and carefully controlled studies have shown bans do encourage quitting."

In Canada, there are 45000 smoking-related deaths annually. The direct health care cost from tobacco use was $\$ 1.36$ billion in 2002, reports the Canadian Centre on Substance Abuse. Steve Smith, Montréal

DOI:Io.I503/cmaj.060683

\section{"It's time to act"}

$\mathrm{T}$ hat's the message Médecins Sans Frontières is taking on the road to 8 cities in Ontario and Quebec this summer. MSF's interactive touring exhibit gives Canadians a chance to join an MSF team in one of 4 countries (Sierra Leone, Bolivia, South Africa or Uzbekistan) and learn about neglected diseases (respectively, malaria, Chagas, HIV and tuberculosis).

"The average Canadian doesn't know anything about [these diseases] that are major health problems around the world," says Dr. Peter Saranchuk, a St. Catharines, Ont. physician who has done 2 MSF missions in Africa.

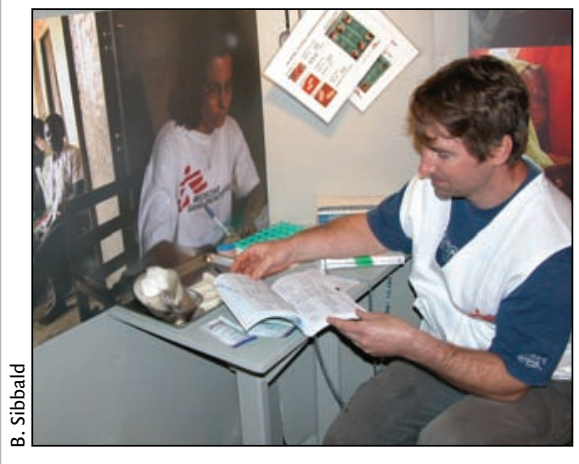

MSF team member Dr. Peter Saranchuk in the touring exhibit's simulated clinic office

In South Africa, 6.5 million people need antiretrovirals (ARVs); $25 \%$ have access. But $18 \%$ of people now have resistance to first-line ARVs; second-line meds cost about $\$ 5000$ a year, compared to \$19o for first-line. Given former prime minister Jean Chrétien's Pledge to Africa program, "It will be interesting to see what happens in Canada," says Saranchuk, who is touring with the exhibit. 
The exhibit aims to "bring attention to the plight of millions of people worldwide who do not have access to affordable medicines," says MSF-Canada President Dr. Joanne Liu.

If it's successful, a cross-Canada tour may take place next year. - Barbara Sibbald, $C M A J$

DOI:I0.1503/cmaj.06o682

\section{News@aglance}

Fitness failure: Canada's children got a " $D$ " for the second year running on the annual report card on physical activity from Active Health Kids Canada. The charitable advocacy group is calling for more information about the importance of: unstructured physical activity and play time; cutting back on TV and computer time; and, establishing quality health and phys-ed classes. Chair, Dr. Mark Tremblay says parents and caregivers can set a good example by being active themselves, but only $36 \%$ do so.

Record spending: The estimated total health spending among Canada's provinces and territories for 2006-07 is expected to reach $\$ 84.7$ billion, a $\$ 5.7$ billion or $6.4 \%$ increase from the year before. If current rates continue, health spending is expected to exceed \$roo billion next year. Ontario had the biggest outlay $-\$ 35.4$ billion.

CMAJ Interim report: The CMAJ Governance Review Panel released an Interim Progress Report on May 23 highlighting progress to date. The 6-member panel, led by Montréal lawyer, Richard Pound and CMAJOmbudsman Dr. John Dossetor, has met 3 times, received rog submissions and solicited feedback from III medical, editorial, publishing and educational organizations. The Panel has also commissioned a research report from Prof. Gilles Paquet on editorial governance structures at other leading journals. Paquet is a senior research fellow at the Centre on Governance at the University of Ottawa. The panel was created earlier this year to recommend a new governance plan for $C M A J$ and its publisher, CMA Media Inc. Its report is due July I4.
Food fight: The US and European Union have decided not to impose new regulations on the food industry to fight obesity. "The government can't tell someone what to eat," Deputy US Health Secretary Alex Azar told Reuters. Both the US and EU have asked companies, health experts and consumer groups to find other ways to combat obesity. The soft drinks industry on both sides of the Atlantic has agreed to a voluntary ban on ads aimed at children. - Compiled by Barbara Sibbald, CMAJ

DOI:I0.I503/cmaj.06o68o

\section{Pulse}

\section{Drug spending hits $\$ 24.8$}

\section{billion}

$\mathrm{T}$ otal spending on drugs in Canada increased by II\% last year to $\$ 24.8$ billion (see Fig. I), according to the Canadian Institute for Health Information's annual drug expenditures report.

Drug spending consumed $17.5 \%$ of the health care dollar in 2005, up from the $9.5 \%$ share it claimed in I985 when drug outlays tallied $\$ 3.8$ billion.

CIHI surmised the explosive growth in drug spending was attributable to a wide range of factors, including: higher prices for both brand-name and generic drugs, particularly new products, which are typically introduced to the market at very high levels; aggressive marketing of drugs to physicians and direct-to-consumer advertising by industry; changes in prescription and dispensing practices; inflation; the advent of new drug therapies for once untreatable or under-treated diseases, or for disorders once treated by surgery; and demographic changes, ranging from growth and aging of the population to epidemics or emerging new diseases.

With drugs commandeering an ever larger slice of health spending, the system continues to spend a smaller share of its health care dollar on physicians and hospitals. Spending on physicians rose to $\$ \mathrm{I} 8.2$ billion in 2005 from $\$ 6$ billion in 1985 but dropped from $15.2 \%$ of total spending to $\mathrm{I} 2.8 \%$. Hospital spending dropped to $29.9 \%$ from $40.8 \%$. Wayne Kondro, CMAJ

DOI:Io.I503/cmaj.060659

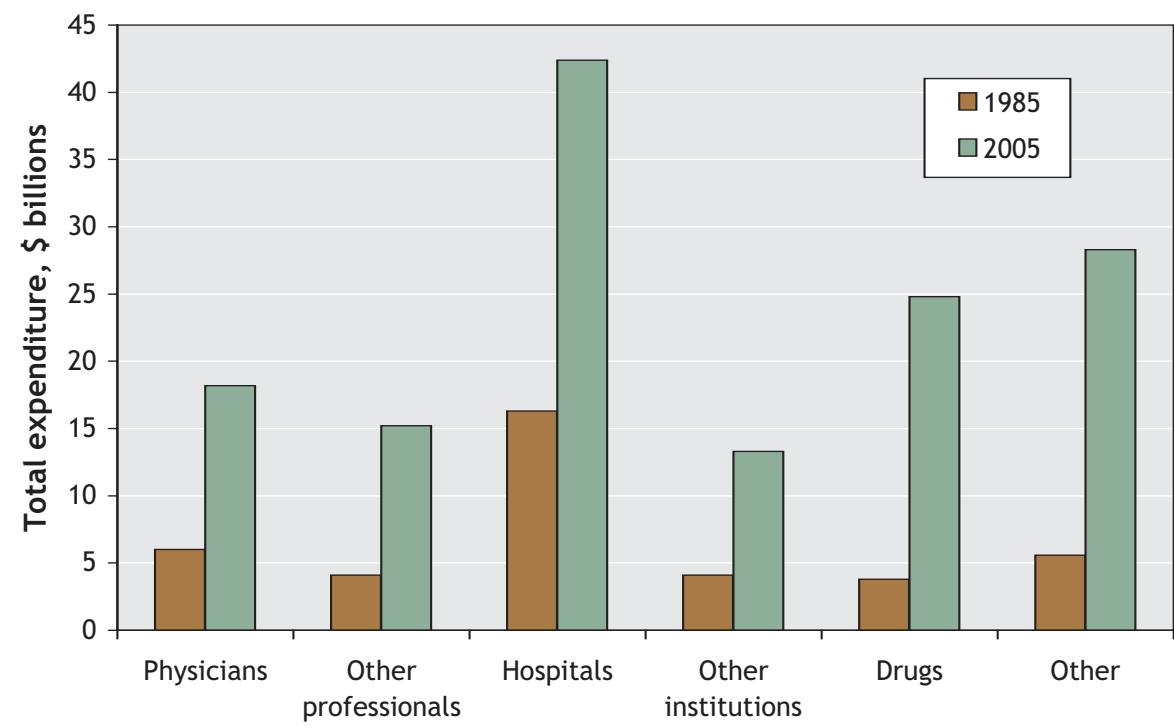

Fig. 1: Change in total health expenditures by use of funds in Canada, 1985 and 2005. The category "other" includes public health, administration, capital and other health spending. Source: Canadian Institute for Health Information 